\title{
HUBUNGAN POLA BACA MAHASISWA DENGAN PRESTASI AKADEMIK
}

\author{
Prijana*, dan Andri Yanto*
}

Pengutipan: Prijana, dan Yanto, A. (2017). Hubungan pola baca mahasiswa dengan prestasi akademik. Khizanah al-Hikmah : Jurnal Ilmu Perpustakaan, Informasi, dan Kearsipan, 5(1), 50-58.

DOI: http:/ /dx.doi.org/10.24252/kah.v5i1a4

\section{*Program Studi Ilmu Perpustakaan, Universitas Padjadjaran, Bandung prijana@unpad.ac,andri.yanto@unpad.ac.id}

\begin{abstract}
ABSTRAK
Pola baca mahasiswa dalam realita saat ini masih ada 2 (dua) tipe, yakni tipe kebut semalam dan bertahap. Sementara sistem belajar mengajar mengalami perubahan, yakni dari TCL (Teching Centre Learning) menjadi SCL (Student Centre Learning), di mana mahasiswa dituntut belajar mandiri. Penelitian ini bertujuan = untuk mengetahui hubungan prestasi akademik mahasiswa dengan pola baca. Artikel ini merupakakan hasil penelitian eksperimen ( $\mathrm{N}=37)$. Teknik analysis data dengan menggunakan statistika deskriptif, yakni analisis Chi-Square. Adapun hasil penelitian yaitu, pertama, diketahui Chi-square hitung $=4.51$; Jika $\alpha=0.10$; $\mathrm{dk}=4$; makaChi-square tabel $=7.78$; artinya Hipotesis: ditolak. Kedua, diketahui Chi-square ${ }_{\text {hitung }}=8.52$; Jika $\mathrm{a}=0.10 ; \mathrm{dk}=4$; maka Chi-square tabel $=7.78$; artinya Hipotesis: diterima. Kesimpulan penelitian yaitu, team work pengajaran yang konsisten akan memiliki peluang pada capaian prestasi akademik mahasiswa. Sebaliknya team work pengajaran yang tak konsisten akan berpengaruh terhadap prestasi akademik mahasiswa.
\end{abstract}

Kata kunci: Pola baca mahasiswa, prestasi akademi, TC, SCL, tim pengajar

\section{ABSTRACT}

Reading pattern of an undergraduate student in reality still there are two types, i.e. type "cram (Sistem Kebut Semalam)" and gradually. The current system of learning in higher education has been transformed from a system of TCL (Teaching Centre Learning) into SCL (Student Learning Centre), who demanded the students can study independently. The purpose of this research is to know the relationship of academic achievement of students with the reading pattern. The method of research used experiment $(N=37)$. Analysis of the method used is descriptive statistics, namely the Chi-Square analysis. The first research results: Chi-square count $=4.51$; If $a=0.10 ; D F=4$; then the Chi-square table $=7.78$; this means that the hypothesis is rejected. The second research results: Chi-square $=$ count 8.52; If $a=0.10$; $D F=4$; then the Chi-square table $=7.78$; this means that the hypothesis is accepted. The conclusion of this research is the consistent teaching team will have an opportunity at the close of student academic achievement. Instead of team teaching is not consistently will have an effect on student academic achievement.

Key words: Reading pattern, academic achievement, TCL, SCL, team teaching 


\section{PENDAHULUAN}

\section{a. Latar Belakang}

Dalam literatur Ilmu Perpustakaan dan Informasi dikatakan bahwa kegiatan membaca itu merupakan kegiatan artifisial, yakni kegiatan yang dipelajari dan berlangsung terus-menerus, bukan budaya. Prijana \& Saefullah (2015) dalam hasil eksperimennya mengatakan bahwa mahasiswa memiliki keterampilan dan keterlatihan baca yang berbeda satu sama lainnya, dan memiliki kecepatan waktu baca yang berbeda satu sama lainnya. Mereka yang memiliki prestasi akademik lebih tinggi memiliki kecenderungan lebih cepat waktu bacanya dibandingkan dengan mereka yang memiliki prestasi akademik lebih rendah. Mereka yang memiliki prestasi akademik lebih tinggi, memiliki kebiasaan baca yang juga berbeda dengan yang memiliki prestasi lebih rendah. Mereka yang memiliki prestasi akademik lebih tinggi, sering melakukan aktivitas baca dibandingkan dengan yang memiliki prestasi akademik lebih rendah.

Di sini tingkat keseringan baca diartikan sebagai keterlatihan, sehingga dapat dikatakan semakin terlatih membaca, semakin cepat waktu bacanya. Di sini faktor keterlatihan baca menentukan waktu baca dan jumlah kata yang dibaca. Sementara mahasiswa memiliki kebiasaan baca (reading habit), sekali baca teks langsung untuk memahami, dan memiliki pola baca sebagai berikut, kebut semalam dan pola baca bertahap. Dalam hasil eksperimen juga diketahui bahwa kemampuan baca mahasiswa yang nyaman dalam sekali baca teks pada kisaran 1000-2000 kata. Jika mereka dilakukan dalam satu malam, kemampuan efektif baca maksimum diperkirakan hanya 3 (tiga) kali baca atau memiliki rentang 3000- 6000 kata.

Frank Hatt (1976) dalam karya bukunya The Reading Process secara eksplisit mencoba untuk memahami apa itu membaca, who is the reader? Ia katakan "this reader, in existential reading situation, is a person who is literate", yang selanjutnya ia tegaskan lagi bahwa "the reader is a literate person". Sementara Adler \& Doren (1940) pernah mengatakan "reading is tools". Moyle (1973), mengingatkan bahwa membaca buku teks membutuhkan rasa senang (enjoy read), artinya kemampuan seseorang dalam membaca buku teks itu terbatas, tidak mungkin dilakukan secara terus menerus berjam-jam dalam sekali baca. Kondisi dalam diri seseorang yang bertindak sebagai kontrol adalah rasa senang, yang akan membatasi seseorang dalam aktivitas membaca. Di sini yang dimaksud membaca adalah membaca aktif dan membaca pasif. Jika yang dimaksud adalah mengikuti materi perkuliahan, maka aktivitas itu adalah membaca pasif.

Prijana (2016) dalam studi eksperimennya menunjukkan diketahui $(\mathrm{N}=34)$ dan jika $a=0.25 ; \mathrm{df}=2$; maka nilai prestasi akademik mahasiswa memiliki hubungan signifikan dengan kemampuan membaca teks ilmu pengetahuan melalui metode good reading; jika $a=0.10$; df $=2$; maka nilai prestasi akademik mahasiswa memiliki hubungan non-signifikan dengan kemampuan baca teks ilmu pengetahuan melalui metode good reading. Ini menunjukkan metode baca good reading masih diragukan untuk mendongkrak prestasi akademik mahasiswa.

Prijana \& Sukaesih menggambarkan hubungan kemampuan baca mahasiswa melalui metode good reading dengan kemampuan menjawab 
soal multiplechoice, dengan $(\mathrm{N}=34)$ dan jika $\mathrm{a}=0.10 ; \quad \mathrm{df}=4 ; . \quad$ Penelitian ini menunjukkan bahwa kemampuan menjawab soal multiplechoice memiliki hubungan significant dengan metode baca good reading. Di sini kemampuan menjawab soal muitiplechoice memiliki hubungan significant dengan metode baca good reading, dengan derajat kepercayaan $90 \%$.

Prijana \& Yanto (2016) dalam studi eksperimennya yang berjudul: Uji Korelasi tentang prestasi akademik dengan metode baca mahasiswa, dengan $(\mathrm{N}=34)$ dan $a=0.01 ; \mathrm{df}=32$; diketahui prestasi akademik memiliki hubungan korelasi significant dengan metode baca good reading. Disini prestasi akademik memiliki hubungan korelasi significant dengan metode baca good reading, dengan derajat kepercayaan sampai $99 \%$.

Hal lain yang menjadi perhatian adalah adanya hasil simpulan dari penelitian Arnold Riyan pada tahun 2016 yang menunjukkan bahwa faktor dosen memiliki peran yang biasa saja atau moderat terhadap dorongan membaca mahasiswa pada buku teks. Walau demikian, instruksi dosen dalam memberikan tugas-tugas akademik cukup memiliki arti dalam mendorong mahasiswa untuk membaca-buku teks. Hal ini berlaku untuk mahasiswa pada semua jenjang akademik atau dapat dikatakan bahwa tugas-tugas akademik dari dosen mampu mendorong mahasiswa untuk membaca buku teks (Riyan, Prijana \& Sukaesih, 2015).

Berdasarkan hasil paparan di atas, penelitian kali ini akan dilakukan pengujian tentang hubungan prestasi akademik dengan pola baca mahasiswa terkait dengan adanya faktor dosen dalam kegiatan pembelajaran.

\section{b. Rumusan Masalah}

1) Apakah materi kuliah dosen A dan dosen B memiliki efek signifikan pada mahasiswa.

2) Apakah pola baca mahasiswa memiliki hubungan signifikan dengan prestasi akademik.

\section{c. Tujuan Penelitian}

1) Untuk mengetahui efek materi kuliah dosen A dan dosen B.

2) Untuk mengetahui hubungan prestasi akademik dengan pola baca mahasiswa.

\section{KAJIAN PUSTAKA}

Kegiatan membaca bagi kalangan mahasiswa menjadi sebuah tuntutan sebagai bagian dari aktivitas akademik di mana para mahasiswa diharapkan dapat memperoleh informasi tentang topiktopik yang sedang dibahas di perkuliahan dan memiliki minat untuk membaca.

Kegiatan membaca tersebut diharapkan dapat berimplikasi terhadap prestasi akademik para mahasiswa apabila mengetahui bagaimana pola baca, proses membaca sampai pada kemampuan memahami bahan bacaan yang telah mereka baca serta mampu berpikir kritis. Membaca merupakan proses berpikir atau bernalar (proses aktif dan bertujuan) yang dilakukan melalui proses mempersepsi dan memahami informasi serta memberikan makna terhadap bacaan yang dilakukan oleh pembaca melalui kegiatan visual untuk mencocokkan huruf atau melafalkan lambang bahasa tulis untuk memperoleh pesan yang disampaikan penulis (Pandawa, Hairudin \& Sakdiyah, 2009).

Menurut Rivers \& Temperly (1978) dalam Pandawa, Hairudin \& Sakdiyah 
(2009) terdapat tujuh tujuan utama dalam membaca yaitu; a) Memperoleh informasi untuk suatu tujuan atau merasa penasaran tentang suatu topic, b) Memperoleh berbagai petunjuk tentang cara melakukan suatu tugas bagi pekerjaan atau kehidupan sehari-hari (misalnya, mengetahui cara kerja alat-alat rumah tangga), c) Berakting dalam sebuah drama, bermain game, menyelesaikan teka-teki, d) Berhubungan dengan temanteman dengan surat-menyurat atau untuk memahami surat-surat bisnis, e) Mengetahui kapan dan di mana sesuatu akan terjadi atau apa yang tersedia, f) Mengetahui apa yang sedang terjadi atau telah terjadi (sebagaimana dilaporkan dalam koran, majalah, laporan), g) Memperoleh kesenangan atau hiburan.

Membaca sangat terkait dengan pola baca yang digunakan seseorang terkait dengan pengalamannya di lingkungan tempat seseorang tersebut berkembang. Pola baca (reading pattern) menurut Adhim (2004) kecenderungannya dapat dibentuk sejak anak baru lahir melalui penanaman kebiasaan membaca dan berdampak sampai seseorang tersebut hingga dewasa yang pada akhirnya menjadi budaya. Pola baca tersebut sangat terkait dengan aktivitas mahasiswa dalam melakukan kegiatan akademiknya dalam melakukan proses membaca, terdapat mahasiswa dalam proses membacanya secara bertahap, adapula yang melakukan proses membaca menggunakan sistem kebut semalam untuk memahami serta menguasai sebuah topik.

Tujuan membaca menjadi sangat penting sebagai faktor yang mempengaruhi dalam proses membaca dan memahami bahan bacaan. Hubungan antara tujuan membaca dengan kemampuan membaca sangat signifikan. Pembaca yang mempunyai tujuan yang sama, dapat mencapai tujuan dengan cara pencapaian berbeda-beda. (Pandawa, Hairudin \& Sakdiyah, 2009). Pada tingkatan perguruan tinggi, hal yang menjadi perhatian utama dalam kegiatan akademik adalah keterampilan membaca yang membutuhkan pemahaman terhadap suatu topik.

Lebih lanjut dapat dijabarkan dua karakteristik yang penting dalam pembelajaran membaca dalam kegiatan belajar mengajar. Karakteristik tersebut adalah sebagai berikut:

a. Keterampilan yang bersifat mekanis dapat dianggap berada pada urutan yang lebih rendah. Hal ini mencakup: (a) pengenalan bentuk huruf; (b) pengenalan unsur-unsur linguistik (fonem/grafem, kata, frase, pola klausa, kalimat, dan lain-lain); (c) pengenalan hubungan/korespondensi pola ejaan dan bunyi (kemampuan menyuarakan bahan tertulis); (d) kecepatan membaca ke taraf lambat.

b. Keterampilan bersifat pemahaman yang dapat dianggap berada pada urutan yang lebih tinggi. Hal ini mencakup: (a) memahami pengertian sederhana (leksikal, gramatikal, retorikal); (b) memahami signifikansi atau makna (a.l. maksud dan tujuan pengarang, relevansi/keadaan kebudayaan, dan reaksi pembaca); (c) evaluasi atau penilaian (isi, bentuk); (d) kecepatan membaca yang fleksibel, mudah disesuaikan dengan keadaan (Broghton et al., 1978, 211 dalam Tarigan 1978, 12-13). (Pandawa, Hairudin \& Sakdiyah, 2009).

\section{METODOLOGI PENELITIAN}

Metode penelitian yang digunakan adalah eksperimen, yakni menguji hipotesis, menguji keterkaitan variabel bebas (independent variable) dengan 
variabel terikat (dependent variable). Di sini variabel bebas merupakan variabel rekayasa. Sementara variabel terikat adalah konstan. Hasil rekayasa variabel bebas terhadap variabel terikat dapat diuji. David R. Krathwohl (1993) dalam bukunya Methods of Educational and Social Science memberi gambaran sebagai berikut bahwa penelitian eksperimen merupakan penelitian yang paling murni kuantitatif, semua prinsip dan kaidahkaidah penelitian kuantitatif dapat diterapkan pada metode eksperimen (Prijana, Winoto \& Yanto, 2016).

Good dalam Sevilla (2008) memahami metode eksperimen sebagai berikut, paling sedikit dapat dilakukan dalam satu kondisi yang dapat dimanipulasikan. Sementara kondisi yang lain dianggap konstan. Kemudian pengaruh perbedaan kondisi tersebut dapat diuji. Manipulasi kondisi merupakan karakteristik yang membedakan penelitian eksperimen dengan metode lainnya. Variabel bebas dapat diartikan sebagai variabel eksperimen yang karakteristiknya diyakini menghasilkan perbedaan.

John W. Creswell (2010: 229) dalam bukunya yang berjudul Research Design memperhatikan aspek partisipan dalam penelitian eksperimen, seperti cara pemelilihan partisipan, dan ukuran partisipan (size of participant). Cara pemilihan partisipan dapat dilakukan melalui 2 (dua) cara, yakni secara random dan non-random atau yang disebut dengan konvenien (convenien). Dalam eksperimen kali ini menggunakan cara konvenien, yakni tidak menggunakan cara sampling. Di sini unit populasi langsung dijadikan sebagai unit penelitian ( $\mathrm{N}=37)$.

Perlakuannya adalah perlakuan within group design, menguji 1 (satu) kelompok yang diberi perlakuan saja (treatment), partisipan dikelompokkan dalam perlakuan yang berbeda-beda, dalam ruang dan waktu yang berbeda. Perlakuan pertama dilakukan sebut saja dosen A dan perlakuan kedua dilakukan dosen $B$, dengan tema yang sama materi yang berbeda, dalam waktu yang berbeda pula, dan tipe evaluasi yang berbeda. Dosen A memberikan materi 7 (tujuh) kali tatap muka, dan dosen B juga memberikan materi 7 (tujuh) kali tatap muka. Di sini partisipan adalah mahasiswa program studi Ilmu Perpustakaan Fakultas Ilmu Komuniasi Universitas Padjadjaran.

Dosen A didampingi asisten dosen atau sebut saja asisten dosen C. Dosen A hadir di kelas memberikan materi kuliah secara penuh dan asisten dosen $\mathrm{C}$ sit in di kelas mengikuti materi kuliah. Setelah pertemuan ketujuh, dosen A memberi instruksi kepada asisten dosen $C$ untuk membuat soal multiplechoice untuk ujian tengah semester (UTS). Soal ujian dibuat oleh asisten dosen $\mathrm{C}$ dan dikoreksi oleh dosen A. Di sini soal ujian sebagai alat tes selama tujuh kali tatap muka di kelas. Selanjutnya, dosen B juga melakukan hal yang sama. Dosen B memberikan materi kuliah di kelas dan didampingi asisten dosen C. Selama pemberian materi di kelas asisten dosen C lebih banyak memberikan materi kuliah pada mahasiswa dibandingkan dosen B. Setelah pertemuan ketujuh, dosen B menginstruksikan kepada asisten dosen $C$ untuk membuat soal ujian essay (UAS). Soal ujian dimaksudkan sebagai alat tes selama tujuh kali tatap muka. Di sini asisten dosen $C$ cenderung sebagai pihak yang memberi materi kuliah dan sekaligus yang membuat soal.

Selanjutnya metode analisis yang digunakan adalah statistika sosial. Metode analisis yang digunakan adalah statistik deskriptif, yakni analisis kontingensi Chi- 
kuadrat, dengan skala nominal. Prestasi akademik diklasifikasi menjadi 5 (lima) klasifikasi dengan menggunakan metode penilaian PAP (Penilaian Acuan Patokan).

\section{LANDASAN TEORI}

Penelitian di sini dilakukan dua kali, penelitian pertama dilakukan pada kelompok eksperimen $(\mathrm{N}=37)$ dengan treatment tujuh kali oleh dosen A dan asisten dosen $\mathrm{C}$, dan dievaluasi. Penelitian kedua dilakukan pada kelompok eksperimen $(\mathrm{N}=37)$ yang sama dengan treatment tujuh kali oleh dosen $\mathrm{B}$ dan asisten dosen C, dan dievaluasi.

\section{HASIL PENELITIAN DAN PEMBAHASAN}

\section{a. Pertama: Dosen A dan Asisten dosen C}

Tabel 1. Hubungan pola baca mahasiswa dengan prestasi akademik

Pola Baca * Prestasi Akademik Crosstabulation

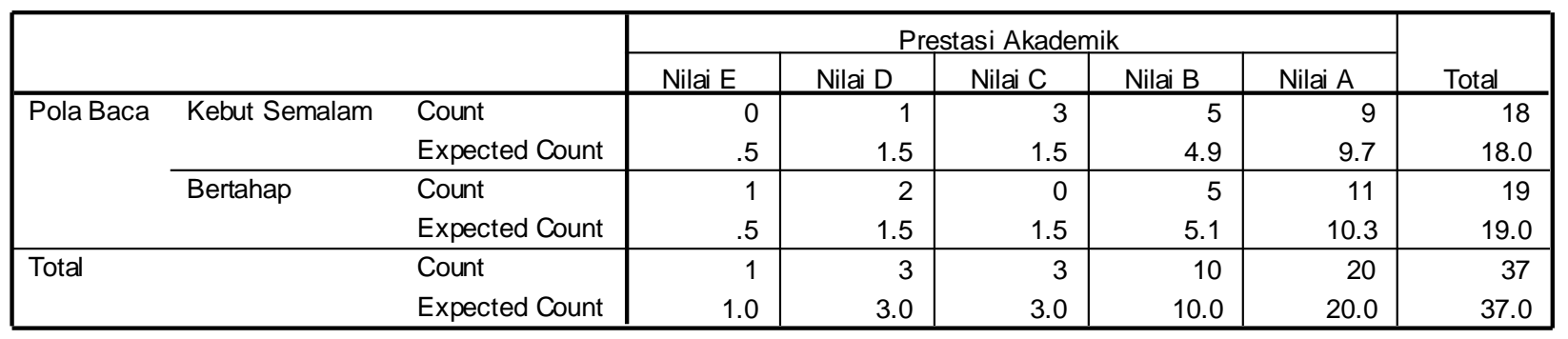

Chi-Square Tests

\begin{tabular}{|l|r|r|r|}
\hline & \multicolumn{1}{|c|}{ Value } & df & \multicolumn{1}{c|}{$\begin{array}{c}\text { Asymp. Sig. } \\
\text { (2-sided) }\end{array}$} \\
\hline Pearson Chi-Square & $4.510^{\mathrm{a}}$ & 4 & .341 \\
Likelihood Ratio & 6.058 & 4 & .195 \\
Linear-by-Linear & .001 & & .974 \\
Association & 37 & 1 & \\
N of Valid Cases & & \\
\hline
\end{tabular}

a. 7 cells $(70.0 \%)$ have expected count less than 5 . The minimum expected count is .49 .
Diketahui Chi-squarehitung $=4.51$; Jika $\mathrm{a}=0.01 ; \mathrm{dk}=4$, maka diketahui Chisquare $_{\text {tabel }}=7.78$ artinya Chi-square hitung
Dalam penelitian pertama, peneliti mencoba membangun hipotesis untuk maksud pengujian hipotesis dengan Chisquare (2X5) sebagai berikut,

H0: Pola baca mahasiswa memiliki hubungan non-signifikan dengan prestasi akademik.

H1: Pola baca mahasiswa memiliki hubungan signifikan dengan prestasi akademik.

Dengan menggunakan program SPSS peneliti dapat mengetahui sel-sel tabel kontingensi mengenai hubungan pola baca mahasiswa dengan prestasi akademik yang dicapai, setelah tujuh kali tatap muka, seperti yang dapat dilihat pada tabel 1 di bawah ini.

\section{$\lambda^{2}=4.51$}


mahasiswa yang mana di sini hanya dapat diketahui, namun tak dapat disebutkan satu persatu.

\section{b. Kedua: Dosen B dan Asisten Dosen C}

Dalam penelitian kedua, peneliti mencoba membangun hipotesis untuk maksud pengujian hipotesis dengan Chisquare (2X5) sebagai berikut,

H0: Pola baca mahasiswa memiliki hubungan non-signifikan dengan prestasi akademik.
H1 : Pola baca mahasiswa memiliki hubungan signifikan dengan prestasi akademik.

Dengan menggunakan program SPSS peneliti dapat mengetahui sel-sel tabel kontingensi mengenai hubungan pola baca mahasiswa dengan prestasi akademik yang dicapai, setelah tujuh kali tatap muka, seperti yang dapat dilihat pada tabel 2 di bawah ini.

Tabel 2. Hubungan pola baca mahasiswa dengan prestasi akademik

Pola Baca * Prestasi Akademik Crosstabulation

\begin{tabular}{|lll|r|r|r|r|r|}
\hline & & \multicolumn{3}{|c|}{ Prestasi Akademik } & \multicolumn{1}{c|}{ Total } \\
\cline { 3 - 7 } & & Nilai D & \multicolumn{1}{c|}{ Nilai C } & Nilai B & \multicolumn{2}{c|}{ Nilai A } & \multicolumn{1}{c}{ Total } \\
\hline Pola Baca & Kebut Semalam & Count & 7 & 5 & 4 & 2 & 18 \\
& & Expected Count & 5.8 & 2.4 & 6.3 & 3.4 & 18.0 \\
\cline { 2 - 7 } & Bertahap & Count & 5 & 0 & 9 & 5 & 19 \\
& & Expected Count & 6.2 & 2.6 & 6.7 & 3.6 & 19.0 \\
\hline Total & Count & 12 & 5 & 13 & 7 & 37 \\
& & Expected Count & 12.0 & 5.0 & 13.0 & 7.0 & 37.0 \\
\hline
\end{tabular}

Chi-Square Tests

\begin{tabular}{|l|r|r|r|}
\hline & \multicolumn{1}{|c|}{ Value } & df & $\begin{array}{c}\text { Asymp. Sig. } \\
\text { (2-sided) }\end{array}$ \\
\hline Pearson Chi-Square & $8.521^{\mathrm{a}}$ & 3 & .036 \\
Likelihood Ratio & 10.541 & 3 & .014 \\
Linear-by-Linear & 3.292 & & 1 \\
Association & 37 & & .070 \\
N of Valid Cases & & \\
\hline
\end{tabular}

a. 4 cells $(50.0 \%)$ have expected count less than 5 . The minimum expected count is 2.43 .
Diketahui Chi-square hitung $=8.52$; Jika a $=0.01 ; \mathrm{dk}=4$, maka diketahui Chisquare $_{\text {tabel }}=7.78$ artinya Chi-square

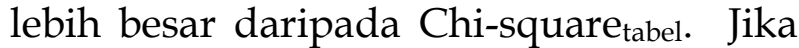
Chi-square hitung lebih besar daripada Chisquare $_{\text {tabel, }}$ maka hubungan pola baca mahasiswa memiliki hubungan signifikan dengan prestasi akademik. Di sini Hipotesis: diterima. Jika Hipotesis diterima dengan derajat kepercayaan 90\%, maka artinya nilai prestasi akademik mahasiswa ( nilai A, B, C, D, dan E ) memiliki keterkaitan dengan pola baca mahasiswa, yakni pola kebut semalam ataupun pola bertahap. Dalam tabel kontingensi juga tampak bahwa pola baca bertahap memiliki perolehan nilai mutu akademik tinggi. Sementara pola baca kebut semalam memiliki kecenderungan dengan nilai mutu akademik lebih rendah.

Pada penelitian pertama, dosen A memberikan materi kuliah secara penuh, dan asisten dosen $\mathrm{C}$ hadir di kelas. Materi kuliah diberikan selama tujuh kali tatap muka, dengan satu kali tatap muka memiliki bobot 3 SKS. Sementara mahasiswa menyimak dan sekali-kali mencatat materi kuliah. Setelah tujuh kali pertemuan, asisten dosen C diberikan wewenang untuk membuat soal ujian 
multiplechoice. Di sini dosen A cukup memeriksa soal-soal yang dibuat asisten dosen C. Pada penelitian kedua, dosen B memberikan materi kuliah secara kurang penuh, dan asisten dosen $\mathrm{C}$ lebih banyak memberikan materi kuliah. Sementara mahasiswa menyimak dan sekali-kali mencatat materi kuliah. Setelah tujuh kali pertemuan, asisten dosen $\mathrm{C}$ diberi wewenang untuk membuat soal ujian.

Di sini tampak bahwa pada penelitian pertama, pemberi materi dengan pembuat soal ujian adalah berbeda. Sementara pada penelitian kedua, pemberi materi dengan pembuat soal ujian adalah relatif sama. Kesamaan antara pemberi materi dengan pembuat soal ujian tampaknya memiliki hubungan dengan prestasi akademik mahasiswa. Ketika pemberi materi dengan pembuat soal adalah berbeda, maka pola baca mahasiswa tidak memiliki hubungan signifikan dengan prestasi akademiknya, pada $\mathrm{a}=0.10 ; \mathrm{dk}=4$. Namun ketika pemberi materi dengan pembuat soal ujian adalah sama, maka pola baca mahasiswa memiliki hubungan signifikan dengan prestasi akademiknya, pada $\mathrm{a}=0.10 ; \mathrm{dk}=4$.

\section{KESIMPULAN}

a. Jika pemberi materi dengan pembuat soal adalah dosen yang sama, maka pola baca mahasiswa memiliki keterkaitan signifikan dengan prestasi akademik, atau dapat dikatakan pola baca mahasiswa berkaitan dengan capaian prestasi akademik.

b. Pola baca dengan cara bertahap memiliki keunggulan dibandingkan dengan pola baca dengan cara kebut semalam.

c. Team work pengajaran/dosen yang konsisten memiliki peluang pada capaian prestasi akademik mahasiswa. Sebaliknya team work pengajaran/dosen yang tak konsisten akan mengganggu prestasi akademik mahasiswa. Di sini artinya pemberi materi kuliah sekaligus bertindak sebagai pembuat soal ujian.

\section{DAFTAR PUSTAKA}

Adhim, M. F. (2004). Membuat anak gila membaca. Bandung: Mizania.

Adler, M. J. \& Doren, C. V. (1972). How to read abook. New York: Simon \& Schuster.

Babbie, E. (2008). The basics of social research. (4th edition). CA: Thomson.

Fisher, K. E. (2008). Theories of information behavior. New Delhi: Ess Publication.

Hatt, F. (1986). The reading process: a framework for analysis and description. Londo: Clive Bingley.

Krathwohl, D. R. (1993). Methods of educational and social science. New York: Longman.

Pandawa, N., Hairudin \& Sakdiyah, M. (2009). Pembelajaran membaca. Jakarta: Departemen Pendidikan Nasional.

Prijana. (2016). Relationship to Read the Text of Knowledge Science through Good Reading Method with Value Achievement as an Academic. In The 2016 International Conference on Media (pp. 799-805). Bandung: Unpad Press.

Prijana, Winoto, Y., \& Yanto, A. (2016). Metode penelitian kuantitatif Ilmu Perpustakaan dan Informasi. Bandung: Unpad Press.

Prijana, Erwina, W. \& Winoto, Y. (2016). Model dan teori ilmu perpustakaan dan informasi. Bandung: Unpad Press. 
Prijana \& Semendison, I. (2005). Metode sampling terapan. Bandung: Humaniora.

Prijana \& Sukaesih (2016). Hubungan kemampuan baca mahasiswa melalui metode good reading dengan kemampuan menjawab soal multiplechoice. EduLib, 6(2), 129137. doi: http://dx.doi.org/10.17509/edulib.v 6i2.5059.g3572

Riyan, A., Prijana, Sukaesih. (2015). Potensi Membaca Buku Teks (Studi Pada Mahasiswa Program Studi Ilmu Perpustakaan Fakultas Ilmu Komunikasi Universitas Padjadjaran Bandung). Jurnal Kajian Informasi dan Perpustakaan, 3(2), 81-88. doi: http://dx.doi.org/10.24198/jkip.v3i 1.9491

Sevilla, C. G. (2008). Pengantar metode penelitian. Jakarta: UI Press.

Singarimbun, M. \& Effendi, S. (1989). Metode penelitian survai. Jakarta: LP3ES.

Sudjana (2005). Metoda statistika.

Bandung: Transito. 